\title{
PENGUKURAN ONLINE TRUST BUILDING MECHANISM TERHADAP REPURCHASE INTENTIONS MENGGUNAKAN METODE APRIORI PADA MARKETPLACE TOKOPEDIA
}

\author{
Dyah Ayu Komala ${ }^{1}$, Hendri ${ }^{2}$, Achmad Maezar Bayu $\mathrm{Aji}^{3}$ \\ ${ }^{1}$ Sistem Informasi / Ilmu Komputer / STMIK Nusa Mandiri / dyahayuk2108@nusamandiri.ac.id \\ ${ }^{2}$ Sistem Informasi / Ilmu Komputer / STMIK Nusa Mandiri / hendri.hed@nusamandiri.ac.id \\ ${ }^{3}$ Sistem Informasi / Ilmu Komputer / STMIK Nusa Mandiri / achmad.hed@nusamandiri.ac.id
}

\begin{abstract}
In measuring consumer purchasing patterns it is still difficult for sellers to recognize so as to reduce the level of sales of sellers on the marketplace. Moreover, this purchasing pattern can be used as a reference to improve the sales strategy. Therefore, it is necessary to measure the mechanism of consumer purchase that can potentially make repeated purchases. This problem can be solved using the Apriori method measurement. In this case study has 9 criteria that are well organized, Easy to get the information needed, Very good display, Trustworthy, Clear, Complete, Very helpful / caring, Safe, Comfortable, can be collaborated using Apriori method so that the interconnectedness between criteria makes the process of measuring consumer purchasing patterns easy. The result of this measurement produces two rules, namely If choose C5 then choose C8 with support $87 \%$ and confidence $152 \%$ and If choose C5 then choose C6, C7 with support $87 \%$ and confidence $152 \%$. So it can be known that the benefits of this measurement seller or seller can prioritize C5, C6, C7, C8 where the criteria are Clear, Complete, Very Helpful and Safe.
\end{abstract}

Keywords: Data Mining, A priori Method, E-marketplace, Online Trust Building Mechanism, Repurchase Intentions

\begin{abstract}
ABSTRAK
Dalam pengukuran pola pembelian konsumen masih sulit untuk dikenali oleh penjual sehingga dapat mengurangi tingkat penjualan para penjual di marketplace. Terlebih lagi pola pembelian ini bisa digunakan sebagai acuan untuk meningkatkan strategi penjualan. Oleh karena itu diperlukan pengukuran mekanisme pembelian konsumen yang dapat berpotensi untuk melakukan pembelian secara berulang. Permasalahan ini dapat diselesaikan menggunakan pengukuran metode Apriori. Pada studi kasus ini memiliki 9 kriteria yaitu Tertata dengan baik, Mudah mendapatkan informasi yang dibutuhkan, Tampilan sangat baik, Dapat dipercaya, Jelas, Lengkap, Sangat membantu/peduli, Aman, Nyaman, dapat dikolaborasikan menggunakan metode Apriori sehingga keterkaitan antara kriteria menjadikan proses pengukuran pola pembelian konsumen menjadi mudah. Hasil dari pengukuran ini menghasilkan dua rules, yaitu if choose $\mathrm{C} 5$ then choose $\mathrm{C} 8$ dengan support $87 \%$ dan confidence $152 \%$ dan if choose $\mathrm{C} 5$ then choose C6, C7 dengan support $87 \%$ dan confidence $152 \%$. Sehingga dapat diketahui bahwa manfaat dari pengukuran ini seller atau penjual dapat memprioritaskan C5, C6, C7, C8 dimana kriteria tersebut adalah Jelas, Lengkap, Sangat Membantu dan Aman.

Kata Kunci: Data Mining, Metode Apriori, E-marketplace, Online Trust Building Mechanism, Repurchase Intentions

\section{PENDAHULUAN}

Pada dasarnya proses pengolahan informasi pada suatu kumpulan data dengan menggunakan metode dan algoritma tertentu merupakan proses data mining. Salah satu metode yang seringkali digunakan untuk pengolahan data transaksi yaitu metode analisis asosiasi. Dimana
\end{abstract}


metode ini berguna untuk menemukan pola hubungan tersembunyi antar item dalam sebuah dataset. Apriori diakui performanya mencapai skalabilitas yang baik sehingga algoritma ini cukup popular dalam algoritma analisis asosiasi[1].

Transaksi secara online sudah menjadi hal yang biasa di lingkup masyarakat saat ini. Masyarakat dapat mengetahui informasi mengenai produk maupun layanan dengan mudah dan cepat melalui transaksi secara online. Perubahan perilaku masyarakat yang semula transaksi secara konvensional menjadi transaksi secara online salah satu tandanya ialah berkembangnya e-marketplace di Indonesia. Maraknya transaksi yang dilakukan secara online menjadikan para e-seller atau penjual online harus lebih meningkatkan strategi pemasarannya demi menjaga para konsumennya tetap melakukan pembelian secara berulang. Banyak penjual atau seller yang masih mengabaikan faktor-faktor apa saja yang dapat meningkatkan pembeli untuk melakukan repurchase intentions. Oleh karena itu, Online Trust Building Mechanism ini perlu dilakukan untuk mengetahui ukuran pola pembelian konsumen terhadap repurchase intentions. Ukuran pola pembelian konsumen yang dapat menentukan repurchase intentions disebabkan karena banyak faktor, baik dari segi tampilan web atau bahkan sampai penjelasan produk dari penjual atau seller. Faktor-faktor ini yang akan digunakan untuk mengukur pola pembelian konsumen sehingga para penjual atau seller dapat memahami faktor apa saja yang perlu diutamakan atau diprioritaskan sehingga pembeli dapat memutuskan untuk repurchase intentions. Apabila penjual tidak dapat memahami faktor-faktor tersebut, dapat berakibat pada toko yaitu konsumen pergi atau membeli ke toko lain, atau akan mempertimbangkan jika ingin membeli di waktu mendatang. Tentunya hal ini dapat mengurangi tingkat penjualan.

Situs online marketplace merupakan tempat belanja yang saat ini digemari masyarakat karena menawarkan berbagai kemudahan dalam berbelanja. Selain kemudahan pelayanan pun menjadi hal yang digemari. Pelayanan situs online bisa digunakan untuk menentukan rating online marketplace agar masyarakat tidak salah pilih situs marketplace untuk berbelanja[10].

Salah satu platform e-marketplace yang banyak digunakan adalah Tokopedia. Data yang penulis peroleh dari iPrice, 2019 menunjukkan bahwa pengunjung terbanyak e-marketplace adalah Tokopedia sebanyak 66 juta pengunjung. Berdasarkan data pengunjung Tokopedia, menarik untuk dibangun sistem pola keterhubungannya atau pola kombinasinya. Mekanisme pola keterhubungan yang terjadi menyebabkan pengunjung dan berpontensi untuk melakukan pembelian secara berulang. Hal ini dapat dibuktikan dengan Pengukuran Online Trust Building Mechanism terhadap Repurchase Intenstions menggunakan metode apriori. Metode apriori merupakan teknik data mining untuk menentukan aturan asosiatif kombinasi antar item. Dalam metode apriori ini dapat mengungkapkan pola keterhubungan transaksi yang terjadi.

Berdasarkan latar belakang yang telah dijelaskan, masalah yang dihadapi yaitu bagaimana mekanisme pengukuran online trust building terhadap repurchase intentions dan bagaimana proses penerapan metode Apriori pada online trust building.

Data mining memiliki beberapa aturan, salah satunya adalah aturan asosiasi. Salah satu jenis metode dalam data mining yang menggunakan aturan asosiasi adalah metode apriori. Kumpulan data yang diolah dimana data tersebut telah ditentukan syarat minimum, baik dari nilai support dan nilai confidence digunakan untuk mencari frekuensi dan keterkaitan antar itemset merupakan salah satu kegunaan algoritma apriori[12].

Adapun tujuan dari penulisan ini yaitu memudahkan penjual online dalam hal memahami pontensi pembeli dan mengetahui mekanisme pengukuran kepercayaan pembelian online.

Penulis membuat batasan permasalahan mengenai online trust building mechanism terhadap repurchase intentions untuk lebih memusatkan permasalahan pada tingkat kualitas penggunaan software bagi pengguna dan penjelasan mengenai kelengkapan informasi yang diberikan. Kuesioner dilakukan menggunakan google form.

Salah satu algoritma yang klasik di data mining adalah apriori. Algoritma apriori digunakan untuk mempelajari aturan asosiasi. Fungsi Association Rules (aturan asosiasi) adalah salah satu 
hal penting untuk menemukan pola frekuensi tinggi himpunan antar itemset. Aturan asosiasi adalah salah satu metode aturan yang memiliki tujuan mencari pola kombinasi item yang sering muncul di antara banyak transaksi, dimana setiap transaksi terdiri dari beberapa item, sehingga metode ini akan mendukung sistem rekomendasi penjualan yang dapat memudahkan calon pembeli dalam penentuan transaksi. Hasil dari aturan ini nantinya akan menghasilkan seberapa besar hubungan antar kombinasi item tersebut yang mana disini dikatakan sebagai $\mathrm{X}$ dan $\mathrm{Y}$, dan diperlukan dua ukuran untuk aturan ini, yakni support dan confidence. Support adalah nilai penunjang atau kombinasi sebuah item dalam database dalam bentuk presentase. Sedangkan confidence adalah nilai kuatnya hubungan antar item tersebut dalam sebuah apriori. Confidence bisa dicari setelah pola frekuensi munculnya sebuah item ditemukan[3]. Hasil perhitungan support dan confidence ini akan menghasilkan Association Rules (aturan asosiasi).

\section{HASIL, ANALISA DATA DAN PEMBAHASAN}

Dalam data mining analisis asosiaisi terbagi menjadi dua tahapan. Tahapan yang pertama yaitu analisis pola frekuensi tinggi. Pola frekuensi dikatakan tinggi apabila suatu kombinasi item tersebut dapat memenuhi syarat minimum dari nilai support. Tahapan analisis pola frekuensi tinggi inilah tahapan yang bertujuan untuk mencari kombinasi item tersebut. Rumus memperoleh nilai support seperti yang ditunjukkan pada persamaan (1) dan (2).

$$
\begin{aligned}
& \text { Support_A } A=\frac{\text { Jumlah_transaksi_mengandung_A }}{\text { Total_Transaksi }} \\
& \text { Suppont_A } \bar{t} \cap B=\frac{\text { Jumlah_transaksi_mengandung_A\&B }}{\text { Total_Transaksi }}
\end{aligned}
$$

Tahapan yang kedua yaitu pembentukan aturan assosiatif. Menemukan aturan asosiatif dimana aturan asosiatif tersebut dapat memenuhi syarat minimum untuk confidence. Rumus memperoleh nilai confidence $\mathrm{A} \rightarrow \mathrm{B}$ adalah sebagai berikut:

Confidence_AB $=\frac{\text { Jumlah_transaksi_mengandung_A } A \& B}{\text { Total_Transaksi_A } A}$

Dalam membangun hubungan yang baik antara penjual dan pembeli dibutuhkan customer trust. Hal ini sangat penting karena antara penjual dan pembeli tidak bertatap muka secara langsung. Dalam menjalankan bisnis secara online, ada beberapa faktor yang perlu diperhatikan. Faktor yang dapat dibangun yaitu ability, benevolence of business dan integrity toko. Faktor-faktor tersebut akan meningkatkan online trust building mechanism. Dapat disimpulkan bahwa semua model online trust building mechanism dibagi menjadi 3 (tiga), Ability, menekankan pada kemapuan profesionalisme penjual. Model ini mencakup kejujuran, keterbukaan, dan kepedulian. Yang diperhatikan konsumen pada model ini adalah kehandalan toko, relevan serta akurat dan kemudahan dalam mendapat informasi. Benevolence of business, lebih menekankan pada kebaikan dan kemurahan hati bagi kesejahteraan pembeli. Komunikasi yang baik menjadi salah satu penunjang dalam online trust building mechanism. Integrity, model ini berarti dapat diandalkan dan konsisten serta sesuai dengan apa yang telah diucapkan dan ditetapkan.

Repurchase intentions atau disebut intensi pembelian merupakan tujuan utama penjualan online. Repurchase intentions atau intensi pembelian dipengaruhi oleh berbagai kecemasan yang dirasakan pembeli akan resiko-resiko yang kemungkinan terjadi. Repurchase intentons dipengaruhi oleh 3 (tiga) model online trust building mechanism. Menurut Zeng, Zuahao, Rong dan Zhilin pada tahun 2009 intensi pembelian atau repurchase intentions akan terjadi pada suatu produk sebanyak dua kali atau bahkan bisa lebih dan bisa terjadi pada produk yang sama atau berbeda. Indikator kepuasan dari sebuah pembelian adalah repurchase intentions.

Mengukur mekanisme online trust building mechanism merupakan mekanisme yang dilakukan untuk mengetahui tingkat kepercayaan pembeli sehingga berpotensi untuk melakukan pembelian kembali. Tokopedia menjadi objek pengukuran dalam penelitian ini karena $e$ - 
marketplace tersebut memiliki pengunjung terbanyak. Dalam penelitian terdahulu penilaian dibatasi persepsi kualitas, pelayanan, dan merek, sedangkan dalam penelitian ini, peneliti ingin menambahkan beberapa penilaian baru [9].

Instrument penelitian adalah peralatan yang digunakan untuk membantu memudahkan proses pengolahan data supaya proses pengolahannya lebih mudah dan mendapatkan hasil yang baik. Ini berarti, dengan menggunakan alat-alat tersebut data Identifikasi Masalah, Akuisisi Data, Pra Pemrosesan Data, Tahapan Asosiasi, Hasil dan Penarikan Kesimpulan dikumpulkan. Instrument sangat penting untuk membantu perolehan data dilapangan. Informasi didapatkan dengan bantuan pedoman dari instrument penelitian ini baik mengenai wawancara proses pengamatan maupun daftar pertanyaan. Instrument itu bisa disebut pedoman kuesioner, maka dalam pembuatan kuesioner penulisan penelitian ini berpedoman pada instrument penelitian sesuai dengan metode yang dipergunakan. Penulisan penelitian ini menggunakan pendekatan penelitian kuantitatif, dalam penelitian ini alat pengumpulan datanya mengacu pada kuesioner atau pada hal yang digunakan peneliti untuk mengumpulkan data. Hal pokok dari penelitian kuantitatif adalah orang yang diteliti (responden) dapat mengisi sendiri kuisioner tanpa kehadiran peneliti atau tanpa bertatap muka.

Penelitian dilakukan di e-marketplace Tokopedia dengan membandingkan dan mengukur nilai yang dapat mempengaruhi online trust building mechanism terhadap repurchase intentions yang didapat dari kriteria-kriteria penilaian terkait seperti pelayanan dan kualitas penggunaan software Tokopedia menggunakan metodeapriori untuk mengetahui pola transaksi konsumen yang berpontensi untuk melakukan pembelian secara berulang.

Data perlu diolah, ditafsirkan dan dikelompokkan. Kegiatan inilah yang disebut analisis data. Dalam penelitian ini metode analisis yang digunakan adalah penelitian kuantitatif. Data yang akan di analisis merupakan data yang telah didapat dan dikumpulkan adalah data hasil kuesioner.

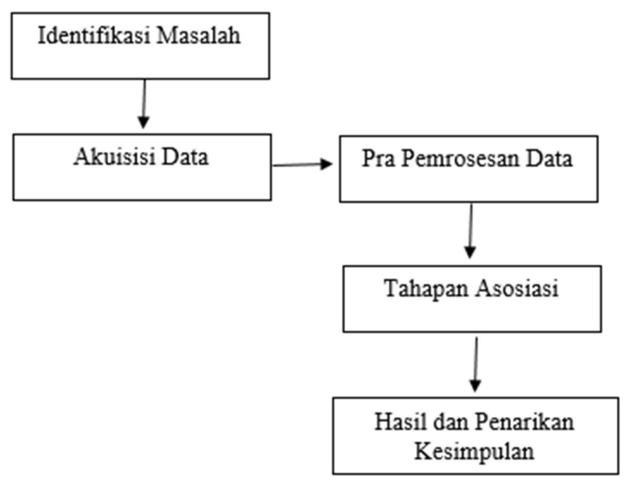

Gambar 1. Tahapan Penelitian

Akuisisi data, pada tahap ini peneliti melakukan pengumpulan data dan informasi yang berkaitan dengan masalah yang akan peneliti ukur yaitu, data untuk pengukuran online trust building mechanism belum jelas ukurannya dan mengukur nilai online trust building mechanism terhadap repurchase intentions. Data yang berasal dari kuesioner.

Pra pemrosesan data fokus dan tujuan dari penelitian ini akan memaksimalkan hasil penelitian. Dalam kasus ini tujuannya adalah untuk mengukur online trust building mechanism terhadap repurchase intentions.

Tahapan Asosiasi, pada tahap ini peneliti melakukan perhitungan support dan confidence. Dalam penelitian ini memakai program Microsoft Excel 2016 dan Rapidminer untuk melakukan perhitungan dalam menentukan pengukuran nilai. 
Tahapan dalam implementasi pada penelitian ini adalah pengumpulan data primer atau obyek. Dalam hal ini kriteria ditentukan dari penilaian para pengguna e-marketplace Tokopedia. Kriteria pengukuran dalam proses pengukuran yaitu, tertata dengan baik, mudah mendapatkan informasi yang dibutuhkan, tampilan sangat baik, dapat dipercaya, jelas, lengkap, sangat membantu/peduli, aman, nyaman.

Hasil penelitian dan penarikan kesimpulan, menganalisa hasil pengolahan data dengan menggunakan perhitungan metode apriori sehingga diperoleh hasil pengukuran pengolahan data secara manual dalam pengukuran online trust building mechanism terhadap repurchase intentions.

Populasi dalam penelitian ini adalah para pengguna Tokopedia. Karena penelitian ini menggunakan teknik probabilitas Sampel dimana semua item pada populasi mempunyai kesempatan yang sama untuk terpilih menjadi item sampel.

\section{HASIL}

Penelitian dimulai dari data transaksi yang di dapat dari data pembeli marketplace tokopedia. Dilakukannya pengukuran ini berdasarkan kriteria yang telah ditentukan yaitu dari kriteria 1 sampai kriteria 9 seperti yang telah disebutkan sebelumnya.

Kriteria yang digunakan dalam pengujian data-data pembeli adalah berdasarkan pada pola (rules) dan nilai confidence (c) yang diperoleh dari hasil pengujian secara manual dan hasil pengujian aplikasi RapidMiner, yaitu: pola (rules) sebanyak 3 (tiga) pola (rules) dan nilai confidence (c) = $80 \%$. (1) jika hasilnya sama antara pola (rules) dan nilai confidence perhitungan manual dengan nilai hasil pengujian aplikasi RapidMiner, maka tingkat keakuratan pengujian sangat tinggi; (2) jika hasilnya mendekati antara pola (rules) dan nilai confidence perhitungan manual mendekati nilai hasil pengujian aplikasi RapidMiner, maka tingkat keakuratan pengujian tinggi; dan (3) jika hasilnya tidak mendekati atau jauh berbeda antara pola (rules) dan nilai confidence hasil perhitungan manual dengan hasil dari aplikasi RapidMiner, maka tingkat keakuratan pengujian rendah atau buruk.

Disini penulis menentukan $\omega$ sesuai dengan kriteria pengujian dari total transaksi. Kriteria disimbolkan dengan huruf $\mathrm{C}$ yaitu:

$$
\mathrm{F}_{1}=\{\{\mathrm{C} 1\},\{\mathrm{C} 2\},\{\mathrm{C} 3\},\{\mathrm{C} 4\},\{\mathrm{C} 5\},\{\mathrm{C} 6\},\{\mathrm{C} 7\},\{\mathrm{C} 8\},\{\mathrm{C} 9\}\}
$$

$\mathrm{C} 1=$ Tertata dengan baik

$\mathrm{C} 2=$ Mudah mendapatkan informasi yang dibutuhkan

C3 $=$ Tampilan sangat baik

$\mathrm{C} 4=$ Dapat dipercaya

C5 $=$ Jelas

C6 $=$ Lengkap

$\mathrm{C} 7$ = Sangat membantu/peduli

$\mathrm{C} 8=$ Aman

C9 = Nyaman

Langkah selanjutnya adalah proses iterasi. Iterasi ini merupakan tahapan dalam pengukuran metode apriori. Iterasi ke 1 di dapat dari data transaksi awal atau data pembeli.

Tabel 1. Iterasi 1

\begin{tabular}{|l|l|}
\hline Kandidat Asosiasi & Nilai Support \\
\hline C1 & $85 \%$ \\
\hline C2 & $92 \%$ \\
\hline C3 & $78 \%$ \\
\hline C4 & $64 \%$ \\
\hline C5 & $57 \%$ \\
\hline C6 & $64 \%$ \\
\hline C7 & $71 \%$ \\
\hline C8 & $71 \%$ \\
\hline C 9 & $57 \%$ \\
\hline
\end{tabular}


Untuk perhitungan nilai support bias dilihat pada persamaan (1).

Kemudian iterasi ke 2 yaitu jumlah frekuensi itemset dilambangkan dengan simbol $\sum$. Jumlah frekuensi itemset harus lebih besar atau sama dengan jumlah frekuensi item set $\left(\sum \geq \emptyset\right)$. Kandidat asosiasi pada iterasi ke 2 terdiri dari dua kriteria yang berbeda kemudian dihitung nilai support nya.

Tabel 2. Iterasi 2

\begin{tabular}{|l|l|}
\hline Kandidat Asosiasi & Nilai Support \\
\hline C1,C2 & $100 \%$ \\
\hline C1,C3 & $91 \%$ \\
\hline C1,C4 & $75 \%$ \\
\hline C1,C5 & $66 \%$ \\
\hline C1,C6 & $75 \%$ \\
\hline C1,C7 & $75 \%$ \\
\hline C2,C3 & $84 \%$ \\
\hline C5,C7 & $100 \%$ \\
\hline C5,C8 & $87 \%$ \\
\hline C5,C9 & $50 \%$ \\
\hline C6,C7 & $77 \%$ \\
\hline C6,C 8 & $77 \%$ \\
\hline C6,C 9 & $44 \%$ \\
\hline C $7, C 8$ & $36 \%$ \\
\hline C $8, C 9$ & $70 \%$ \\
\hline
\end{tabular}

Iterasi ke 3 yaitu Kombinasi pada item F2 atau 2 unsur itemset dapat digabungkan menjadi calon 3 itemset. Item-item set yang memiliki kesamaan pada k-1 item pertama inilah yang dapat digabungkan menjadi calon 3 itemset. Misalnya $\{\mathrm{C} 1, \mathrm{C} 2\}$ dan $\{\mathrm{C} 1, \mathrm{C} 7\}$ memiliki item set k-1 pertama yang sama yaitu $\mathrm{C} 1$ maka dapat digabungkan menjadi 3 item set yang baru yaitu $\{\mathrm{C} 1, \mathrm{C} 2, \mathrm{C} 7\}$. Untuk $\mathrm{k}=3$ (3 unsur) himpunan yang terbentuk. Kandidat asosiasinya pun sama seperti iterasi ke 2 dihitung nilai support nya.

Tabel 3. Iterasi 3

\begin{tabular}{|l|l|}
\hline Kandidat Asosiasi & Nilai Support \\
\hline C1,C2,C3 & $91 \%$ \\
\hline C3,C4,C7 & $72 \%$ \\
\hline C3,C4,C8 & $63 \%$ \\
\hline C3,C7,C8 & $36 \%$ \\
\hline C4,C6,C7 & $77 \%$ \\
\hline C5,C6,C7 & $87 \%$ \\
\hline C5,C7,C 8 & $50 \%$ \\
\hline
\end{tabular}

Iterasi selanjutnya sudah tidak dapat dilakukan sehingga F4 dan seterusnya merupakan himpunan kosong. Rule yang dipakai adalah if $x$ then $y$, yang mana $x$ yaitu antecendent sedangkan $y$ yaitu consequent. Berdasarkan rule tersebut, sehingga dibutuhkan item dimana sebagai antecendent dan sisanya sebagai consequent. Dari langkah sebelumnya maka didapat rule. Dibuat tabel kandidat association rule. 
Jurnal Inkofar * Volume 1 No. 2 Desember 2020 * ISSN: 2615-3645 (Print) / 2581-2920 (Online)

Tersedia secara online di: http://www.politeknikmeta.ac.id/meta/ojs/

Tabel 4. Kandidat Association Rule

\begin{tabular}{|c|c|c|c|}
\hline Aturan asosiatif/rule & $\begin{array}{l}\text { Support } \\
(\mathrm{A} \cap \mathrm{B})\end{array}$ & $\begin{array}{l}\text { Support } \\
\text { (A) }\end{array}$ & Confidence \\
\hline $\begin{array}{l}\text { If choose C1 then } \\
\text { choose } \mathrm{C} 2\end{array}$ & $100 \%$ & $85 \%$ & $117 \%$ \\
\hline $\begin{array}{l}\text { If choose C1 then } \\
\text { choose } \mathrm{C} 3\end{array}$ & $91 \%$ & $85 \%$ & $107 \%$ \\
\hline $\begin{array}{l}\text { If choose C2 then } \\
\text { choose } \mathrm{C} 3\end{array}$ & $84 \%$ & $92 \%$ & $91 \%$ \\
\hline $\begin{array}{l}\text { If choose C3 then } \\
\text { choose } \mathrm{C} 4\end{array}$ & $81 \%$ & $78 \%$ & $103 \%$ \\
\hline $\begin{array}{l}\text { If choose C3 then } \\
\text { choose C7 }\end{array}$ & $81 \%$ & $78 \%$ & $103 \%$ \\
\hline $\begin{array}{l}\text { If choose C3 then } \\
\text { choose } \mathrm{C} 8\end{array}$ & $81 \%$ & $78 \%$ & $103 \%$ \\
\hline $\begin{array}{l}\text { If choose C4 then } \\
\text { choose C6 }\end{array}$ & $88 \%$ & $64 \%$ & $137 \%$ \\
\hline $\begin{array}{l}\text { If choose C4 then } \\
\text { choose } \mathrm{C} 7\end{array}$ & $88 \%$ & $64 \%$ & $137 \%$ \\
\hline $\begin{array}{l}\text { If choose C5 then } \\
\text { choose C6 }\end{array}$ & $100 \%$ & $57 \%$ & $175 \%$ \\
\hline $\begin{array}{l}\text { If choose C5 then } \\
\text { choose } \mathrm{C} 7\end{array}$ & $100 \%$ & $57 \%$ & $175 \%$ \\
\hline $\begin{array}{l}\text { If choose C5 then } \\
\text { choose } \mathrm{C} 8\end{array}$ & $87 \%$ & $57 \%$ & $152 \%$ \\
\hline $\begin{array}{l}\text { If choose C1 then } \\
\text { choose } \mathrm{C} 2, \mathrm{C} 3\end{array}$ & $91 \%$ & $85 \%$ & $107 \%$ \\
\hline $\begin{array}{l}\text { If choose C5 then } \\
\text { choose } \mathrm{C} 6, \mathrm{C} 7\end{array}$ & $87 \%$ & $57 \%$ & $152 \%$ \\
\hline
\end{tabular}

Setelah didapat support dan confidence untuk masing-masing kandidat lakukan perkalian antara support dan confidence dimana confidence nya diambil $80 \%$ ke atas.

Tabel 5. Perkalian Support dan Confidence

\begin{tabular}{|l|l|l|l|}
\hline Aturan asosiatif/rule & Support & Confidence & $\begin{array}{l}\text { Support x } \\
\text { Confidence }\end{array}$ \\
\hline $\begin{array}{l}\text { If choose C1 then } \\
\text { choose } \mathrm{C} 2\end{array}$ & $100 \%$ & $117 \%$ & 1,17 \\
\hline $\begin{array}{l}\text { If choose C1 then } \\
\text { choose C3 }\end{array}$ & $91 \%$ & $107 \%$ & 0,9737 \\
\hline $\begin{array}{l}\text { If choose C2 then } \\
\text { choose C3 }\end{array}$ & $84 \%$ & $91 \%$ & 0.7644 \\
\hline $\begin{array}{l}\text { If choose C3 then } \\
\text { choose C4 }\end{array}$ & $81 \%$ & $103 \%$ & 0,8343 \\
\hline $\begin{array}{l}\text { If choose C3 then } \\
\text { choose C7 }\end{array}$ & $81 \%$ & $103 \%$ & 0,8343 \\
\hline $\begin{array}{l}\text { If choose C3 then } \\
\text { choose C8 }\end{array}$ & $81 \%$ & $103 \%$ & 0,8343 \\
\hline
\end{tabular}


Jurnal Inkofar * Volume 1 No. 2 Desember 2020 * ISSN: 2615-3645 (Print) / 2581-2920 (Online)

Tersedia secara online di: http://www.politeknikmeta.ac.id/meta/ojs/

\begin{tabular}{|l|l|l|l|}
\hline $\begin{array}{l}\text { If choose C4 then } \\
\text { choose } 68 \%\end{array}$ & $137 \%$ & 1,0256 \\
\hline $\begin{array}{l}\text { If choose C4 then } \\
\text { choose C7 }\end{array}$ & $88 \%$ & $137 \%$ & 1,0256 \\
\hline $\begin{array}{l}\text { If choose C5 then } \\
\text { choose C6 }\end{array}$ & $100 \%$ & $175 \%$ & 1,75 \\
\hline $\begin{array}{l}\text { If choose C5 then } \\
\text { choose C7 }\end{array}$ & $100 \%$ & $175 \%$ & $1,75 \%$ \\
\hline $\begin{array}{l}\text { If choose C5 then } \\
\text { choose C8 }\end{array}$ & $87 \%$ & $152 \%$ & 1,3224 \\
\hline $\begin{array}{l}\text { If choose C1 then } \\
\text { choose } \mathrm{C} 2 \mathrm{C} 3 \text { C }\end{array}$ & $91 \%$ & $107 \%$ & 0,9737 \\
\hline $\begin{array}{l}\text { If choose C5 then } \\
\text { choose } \mathrm{C} 6 \mathrm{C} 7\end{array}$ & $87 \%$ & $152 \%$ & 1,3224 \\
\hline
\end{tabular}

Pilih yang hasil perkaliannya paling besar. Karena hasil paling besar dari merupakan rule yang dipakai pada saat pemilihan.

- If choose C5 then choose C8 dengan support $87 \%$ dan confidence $152 \%$

- If choose $\mathrm{C} 5$ then choose C6,C7 dengan support 87\% dan confidence 152\%

Tabel 6. Perbandingan Pengujian Manual dan Pengujian Rapidminer

\begin{tabular}{|l|l|}
\hline Manual & Rapidminer \\
\hline $\begin{array}{l}\text { If choose C5 then choose C8 dengan } \\
\text { support } 87 \% \text { dan confidence } 152 \%\end{array}$ & $\begin{array}{l}\text { If choose C5 then choose C8 dengan } \\
\text { support } 78 \% \text { dan confidence } 91 \%\end{array}$ \\
\hline $\begin{array}{l}\text { If choose C5 then choose C6, C7 dengan } \\
\text { support } 87 \% \text { dan confidence } 152 \%\end{array}$ & $\begin{array}{l}\text { If choose C5 then choose C6,C7 dengan } \\
\text { support } 78 \% \text { dan confidence } 91 \%\end{array}$ \\
\hline
\end{tabular}

Sesuai pola rules yang ada, jika hasilnya mendekati antara pola (rules) dan nilai confidence perhitungan manual mendekati nilai hasil pengujian aplikasi RapidMiner, maka tingkat keakuratan pengujian tinggi.

\section{KESIMPULAN}

Penelitian yang telah dilakukan dengan data mining metode asosiasi dan algoritma apriori serta dilakukannya pengujian dan simulasi dengan aplikasi RapidMiner maka dapat disimpulkan bahwa pengukuran menggunakan algoritma apriori dengan metode asoiasi, kombinasi data yang terbaik di dapat dengan terpenuhinya nilai minimum support dan nilai confidence yang telah ditentukan oleh penulis, yaitu C5, C6, C7, C8, dimana kriteria tersebut adalah Jelas, Lengkap, Sangat Membantu, Aman. Selain itu, data mining algoritma apriori dapat memproses dan di implementasikan dengan menggunakan data pembeli di marketplace Tokopedia karena dapat menemukan kecenderungan pola kombinasi antar itemsets sehingga dapat dijadikan informasi yang penting dalam pengambilan keputusan yang berguna untuk memprioritaskan kriteria yang paling dibutuhkan pembeli. Dari hasil pengukuran ini juga dapat membantu para seller untuk mengatur tokonya di marketplace sesuai dengan apa yang paling diutamakan oleh pembeli sehingga berguna untuk meningkatkan penjualan. Dengan operator algoritma apriori yang diuji dengan aplikasi RapidMiner menghasilkan pola kombinasi itemset dan rules sebagai ilmu pengetahuan dan informasi yang bermanfaat pada suatu toko online. Kekuangan penelitian ini yaitu dataset yang kurang besar dan dapat menggunakan nilai support dan confidence yang lebih beragam sehingga dapat memperoleh banyak asosiasi rules antar item baru. 


\section{DAFTAR PUSTAKA}

Rusydah Ammar Muhammad, Ramadhani Rima Dias, A. A. E. (2018). Optimasi Association Rule pada Keranjang Belanja Pelanggan Menggunakan Apiori dan Algoritma Genetika, $38-43$.

A. Ishak, "Analisis Kepuasan Pelanggan Dalam Belanja Online : Sebuah Studi Tentang Penyebab (Antecedents) dan Konsekuensi (Consequents),"Jurnal Siasat Bisnis, Vol. 16 No. 2, Hal 141-154.

A., Marisa, F., \& Purnomo, D. (2016). Penerapan Algoritma AprioriTerhadap Data Penjualan di Toko Gudang BM. JOINTECS (Journal of Information Technology and Computer Science),

$1(1)$.

Tersedia: https://doi.org/10.31328/jointecs.vli1.408.

Syaifullah, M. A. (2010). Implementasi Data Mining Algoritma Apriori Pada Sistem Penjualan. Stmik Amikom Yogyakarta. Yogyakarta: Sekolah Tinggi Manajemen Informatika Dan Komputer Amikom.

Suryadi, A., \& Harahap, E. (2017). Pemeringkatan Pegawai Berprestasi Menggunakan Metode Ahp (Analytic Hierarchy Process ) Di Pt . Xyz, 16(2), 1-11.

Komputer, D. A. N. T. (2018). Pemberian Reward Berdasarkan Penilaian Kinerja Karyawan dengan Metode AHP pada PT. ANUGERAH, 3(2), 181-188.

Norita, D. (2017). Perilaku Konsumen dalam Berbelanja. Faktor Perilaku Konsumen, 1(1), 11 19.

Artanti, D. P., Syukur, A., Prihandono, A., \& Setiadi, D. R. I. M. (2018). Analisa Sentimen Untuk Penilaian Pelayanan Situs Belanja Online Menggunakan Algoritma Naïve Bayes, $8-9$.

Putra, A. A. C., Haryanto, H., \& Dolphina, E. (2018). Implementasi Metode Association Rule Mining Dengan Algoritma Apriori Untuk Rekomendasi Promo Barang. Csrid, 11, 8999.

Tersedia: http://csrid.potensiutama.ac.id/index.php/CSRID/article/view/277/155.

Z. Arifin, "Kriteria Instrumen dalam suatu Penelitian," J. Theorems (the Orig. Res. Math., vol. 2, no. 1, pp. 28-36, 2017.

\section{UCAPAN TERIMAKASIH}

Terima kasih atas segala doa dan dukungannya sehingga junal ini dapat terbit sesuai harapan penulis. Terima kasih kepada ketua dan wakil ketua STMIK Nusa Mandiri. Terima kasih kepada ketua prodi sistem informasi. Terima kasih kepada pembimbing saya Pak Hendri dan Pak Achmad Maezar Bayu Aji. Terima kasih kepada bapak/ibu dosen. Terima kasih kepada para pengisi kuesioner. Terima kasih kepada orang tua dan teman-teman. 